\title{
Evaluating the Effects of Air Pollution on the Agricultural Yield of Selected Crops in Eleme, Nigeria
}

\section{*1'EKIYOR, TH; ${ }^{2}$ HORSFALL, IT; ${ }^{1}$ KALAGBOR, AI; ${ }^{1}$ EGBARA-DEDUA, BA}

\author{
${ }^{I}$ Department of Laboratory Science, Ken Saro-wiwa Polytechnic Bori, Rivers state, Nigeria. \\ ${ }^{2}$ Department of Agricultural and Bioresources Engineering, College of Engineering and Engineering Technology, Michael Okpara \\ University of Agriculture, Umudike, Abia State, Nigeria. \\ *Corresponding Author Email: tekiyor2@gmail.com
}

\begin{abstract}
This study evaluated the effects of air pollution on agriculture in Eleme, Rivers State, Niger Delta, Nigeria. The air quality in selected locations in Eleme were monitored, as well as crop pathology and laboratory analysis of crops. Although, small-scale subsistence agriculture is the most common farming system practiced in the area. Cassava, pumpkins, plantains, maize and yams are the dominant crops found on the farmlands. It was observed that concentration of sulphur dioxide $\left(\mathrm{SO}_{2}\right)$, nitrogen oxides $\left(\mathrm{NO}_{\mathrm{x}}\right)$, ozone $\left(\mathrm{O}_{3}\right)$ and exceeded the USEPA standards for the protection of crops significantly. While suspended particulate matter (SPM) is slightly high in all sampling locations. However, $\mathrm{O}_{3}, \mathrm{SO}_{2}$ and $\mathrm{NO}_{2}$ and $\mathrm{SPM}$ are the most significant air pollutants that adversely affected the agricultural crops within the area. Although, Cucumber, cocoyam, yams, maize, okras, plantains, cassavas, pumpkins and pawpaw were found to be susceptible to air pollution damage. Statistical analysis showed that there is significant decrease in crop yield between the 2017/2018 harvest season and the 2016/2017 harvest season $(\mathrm{F}=20.3 ; \mathrm{p}<0.05 ; 95 \% \mathrm{Cl}$.). These pollutants can lead to serious reductions of crop growth and yields, a situation which may be aggravated in the future. Air pollution causes approximately $38.3 \%$ crop losses in Eleme annually. Hence, there is need for efficient monitoring and implementation of environmental standards for air quality control by regulatory agencies.
\end{abstract}

DOI: https://dx.doi.org/10.4314/jasem.v23i10.1

Copyright: Copyright $($ C 2019 Ekiyor et al. This is an open access article distributed under the Creative Commons Attribution License (CCL), which permits unrestricted use, distribution, and reproduction in any medium, provided the original work is properly cited.

Dates: Received: 06 July 2019; Revised: 30 September 2019; 12 October 2019

Keywords: statistical analysis; effect of air pollution; agricultural yield; plant pathology; selected crops

Plant injury from ambient air pollutants forms a major consideration in the adoption of air pollution control strategies (Adams et al., 1984). This has prompted several assessments of economic losses caused by air pollution to the agricultural sector. The ability to measure and monitor ambient air pollutant concentration have improved in developed countries with recent advancements in technology. However, in developing countries like Nigeria little research has been carried out measuring the effects of air pollution levels on agriculture. Adams et al. (1984) have identified oxides of sulfur ( $\mathrm{SOx}$ ), oxides of nitrogen (NOx), particulates and ozone $\left(\mathrm{O}_{3}\right)$ as major air pollutants that are insidious to vegetation. Others are secondary pollutants such as photochemical oxidants and acid deposition. Sulfur dioxide $\left(\mathrm{SO}_{2}\right)$ and nitrogen dioxide $\left(\mathrm{NO}_{2}\right)$ are believed to be the primary precursor of acid rainfall and are primarily emitted from stationary sources such as utility and industrial boilers burning coal as a fuel. Both stationary and transportation-related sources, such as refineries (gas flaring), and vehicular emissions contributes to these pollutants. Concentrations of sulphur and nitrogen oxides and hydrocarbons in the atmosphere and in the presence of sunlight undergo a complex series of chemical reactions to form very fine acidic particles such as sulphates and nitrates (Rupakheti, 2015). Nitrogen oxides are also reactive with organic VOCs in the presence of sunlight to form photochemical smog (ground level $\mathrm{O}_{3}$ ). These chemical compounds have been found to cause acid rain, the deposition of which causes damage to crops and reduce soil fertility (Rao and Rao, 2005). In fact, studies have shown that acid rain or deposition directly reduces crops yield (Adams et al., 1984). Study showed that ground level Ozone causes collapse of plant's cell tissue (Hindawi, 1970). This condition causes the formation of redbrown spots in crops.

The land area of Eleme hosts several major industries including two refineries, a petrochemical company and two fertilizer companies. With increased industrial activities couple with the clustering of petroleum activities in the area, air pollution in Eleme is increasing. The combinations of anthropogenic activities in the area result in the release or discharge of noxious gases such as oxides of nitrogen and sulphur, hydrocarbon and ammonia gases into the 
atmosphere. Some of these gases have direct effects on plants and crop yields, while some undergo transformation in the atmosphere to form acidic compounds such as nitric and sulphuric acids. These acids are washed out by rain and deposited on soil resulting in soil infertility. Therefore, this study seeks to evaluate the potential impacts of air pollution on agricultural productivity.

\section{MATERIALS AND METHODS}

Description of the study area: Eleme is located in the coastal area of Rivers State, Nigeria's Niger-Delta between Longitude 706'10" E and Latitude 4047'57" $\mathrm{N}$. The Area occupies the western end of Ogoni-land (UNEP, 2011) with low-laying, flat terrain topography. The major occupation of the people of Eleme is agriculture. The Area hosts a number of oilfields and an Oil Gas free zone. The area also hosts several major national and international establishments including two refineries, a petrochemical company and two fertilizer companies. The East-West highway traverses the length and breadth of Eleme and as a result often experienced heavy vehicular movement. Thus, Air pollutants in semi industrial area of Eleme can be attributed mainly to industrial activities and vehicular emissions influenced by meteorological and geographical conditions of the area. The area is in a tropical climate with a rainy season (April to October) and a dry season (November to March), and often characterized by moderate temperatures and high humidity (Yorkor et al., 2017).

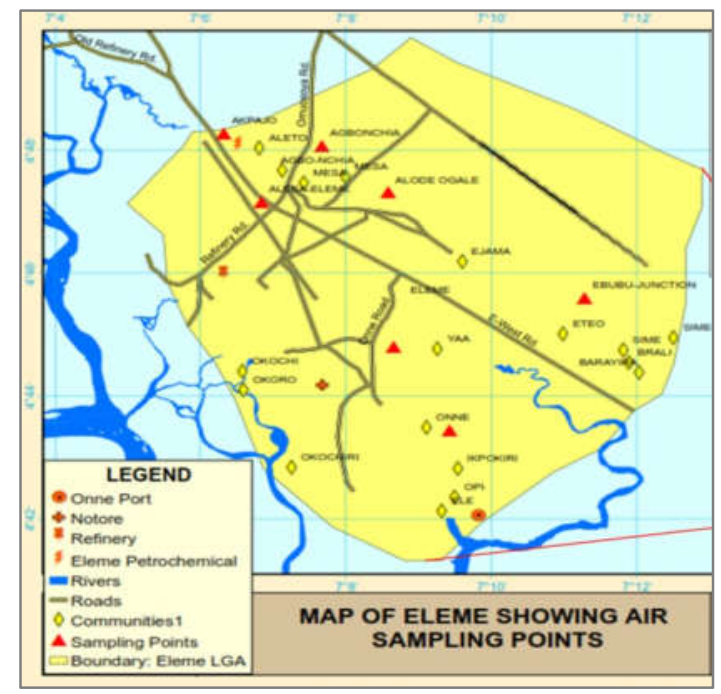

Fig 1: Map of Eleme (source: Yorkor et al., 2017)

Subsistence agriculture is the most common farming system practiced within the study location. It focuses on food crops like, plantain, banana, cassava, maize, yams and cocoyam. Pepper, bitter leaf, vegetables, pineapples, pawpaw, sugar cane, oil palms and coconuts account for about $25 \%$ of the agricultural land use in the area. However, the choice of crops primarily dependents on individual needs. Individual plot holdings range from about $0.05-0.20$ hectares as a result of pressure on the land due to industrial development. Majority of the farmers practiced mix cropping on one plot of land and farmlands are cultivated almost every season. Crops identified within the area are presented in Table 1. Cassava, pumpkins, plantains, maize and yams are the main dominant crops. All the farmlands in the area intersperse with built up areas. Individual compounds are planted with a wide array of economic trees including plantain, banana, palm trees, pawpaw, okra and vegetables primarily for family use. The agricultural lands are connected by a close network of footpaths, which serve as a means of transportation.

\begin{tabular}{|c|c|c|}
\hline No. & $\begin{array}{l}\text { Common } \\
\text { name }\end{array}$ & Botanical name \\
\hline 1 & Cassava & Manihot esculenta \\
\hline 2 & Maize & Zea mays \\
\hline 3 & Yam & Dioscorea \\
\hline 4 & Cocoyam & Colocasia esculenta \\
\hline 5 & Plantain & Musa paradisaca \\
\hline 6 & Pawpaw & Carica papaya \\
\hline 7 & Okra & $\begin{array}{l}\text { Abelmoschus } \\
\text { esculentus }\end{array}$ \\
\hline 8 & Pumpkins & Cducurbita pepo \\
\hline 9 & Cucumber & Cucumis sativus \\
\hline 10 & Red pepper & Capsicum annum \\
\hline
\end{tabular}

Procedure for data collection: Field measurements of the concentrations of air pollutants were carried out insitu. Six sampling locations within the area were selected and their coordinates taken with the aid of a GPS as shown in Table 2.

Table 2. Description of air quality monitoring locations

\begin{tabular}{|c|c|c|}
\hline Sampling points & Coordinate & \\
\hline Akpais Eleme & $\mathrm{N}^{0} 49^{\prime} 25^{\prime \prime}$ & $E 7^{0} 5^{\prime} 10^{\prime \prime}$ \\
\hline Aleto Eleme & $\mathrm{N} 4^{0} 48^{\prime} 46^{\prime \prime}$ & $\mathrm{E} 7^{0} 5^{\prime} 52^{\prime \prime}$ \\
\hline Alode Eleme & $\mathrm{N}^{0} 4645.99^{\prime \prime}$ & $\mathrm{E} 7^{0} 7^{\prime} 34.248^{\prime \prime}$ \\
\hline Alesa Eleme & $N 4^{0} 4653.418^{\prime \prime}$ & $\mathrm{E} 7^{0} 66^{\prime} 50.334^{\prime \prime}$ \\
\hline Agbonchia Eleme & $\mathrm{N} 4^{0} 4747.103^{\prime \prime}$ & $E 7^{0} 7^{\prime} 7.086^{\prime \prime}$ \\
\hline Oxne Eleme & $\mathrm{N} 4^{0} 43^{\prime} 66.368^{\prime \prime}$ & $\mathrm{E} 7^{\circ} 9^{\prime} 29.226^{\prime \prime}$ \\
\hline
\end{tabular}

In the present study, standard air quality monitoring instruments were used to measure the concentrations of air pollutants in the study area as shown in Figures 2. Two Aeroqual series 200 instruments and a GA-21 Plus multi-gas analyzer were used to measure gaseous pollutants. The measurement range and principles of the instruments are shown in Table 3.2. A CW HAT200 Air Particulate Sampler and a mini-volume portable air sampler (Airmetrics ${ }^{\circledR}$ ) with a preweighed membrane filters $(45 \mu \mathrm{m})$ were used to collect suspended particulate matter. After sampling, the 
membrane filters were taken to the laboratory for analysis and the mass concentrations of suspended particulate matter were determined. A multi-purpose digital Kestrel digital weather tracker (model 4500) and a Cup anemometer were used to measure temperature, relative humidity, and wind speed and wind direction. All instruments were calibrated before used in the field for data gathering. Before carrying out sampling and analysis, equipment was checked to assure that they are within calibration tolerances. Field instruments were calibrated by comparing the instrument's response with sampling standards of known concentration level. The difference between the measured and known concentrations was then used to zero the instrument to produce the correct response (Figure 2).

Air quality monitoring procedure: Air quality monitoring at each location in the area was carried out and reading taken in the within 1-hour interval and then averaged up to 8 hours. In order to accurately measure concentrations of pollutants in the air, the instruments were placed at about 1.3 meters above the ground and free of obstruction and interference. Rainy season air quality monitoring was carried in the months of July, August and September, 2018 at Akpajo Eleme, Aleto Eleme, Alode Eleme, Alesa Eleme, Agbonchia Eleme, and Onne Eleme. While, dry season monitoring was carried out at the same locations in the months of December 2018, January and February 2019. Monitoring of air pollutants in the area was conducted to assess the concentration levels of nitrogen oxide $\left(\mathrm{NO}_{2}\right)$, Sulphur Oxides $\left(\mathrm{SO}_{2}\right)$, Carbon oxide (CO), Ozone $\left(\mathrm{O}_{3}\right)$, Methane hydrocarbons, $\left(\mathrm{CH}_{4}\right)$, Ammonia $\left(\mathrm{NH}_{3}\right)$ and suspended particulate matter (SPM), which were pollutants of interest with regard to agriculture. In addition to air pollutants, meteorological parameters such as temperature, relative humidity, wind speed and wind direction were also measured.

Table 3. Instrument measurement range and methodology

\begin{tabular}{llll}
\hline Parameter Range & Resolution & Method \\
\hline $\mathrm{CO}$ & $0-2000 \mathrm{ppm}$ & $0.5 \mathrm{ppm}$ & Electrochemical \\
$\mathrm{NO}_{2}$ & $0.01-200 \mathrm{ppm}$ & $1 \mathrm{ppm}$ & MOS \\
$\mathrm{SO}_{2}$ & $0-50 \mathrm{ppm}$ & $0.01 \mathrm{ppm}$ & FTIR $/ \mathrm{NDIR}$ \\
$\mathrm{O}_{3}$ & $0-0.500 \mathrm{ppm}$ & $0.001 \mathrm{ppm}$ & UV absorption \\
$\mathrm{CH}_{4}$ & $0-100 \mathrm{ppm}$ & $0.01 \mathrm{ppm}$ & Electrochemical \\
$\mathrm{NH}_{3}$ & $0-20 \mathrm{ppm}$ & $0.1 \mathrm{ppm}$ & Electrochemical \\
$\mathrm{SPM}$ & $0.000-1.000 \mathrm{mg} / \mathrm{m}^{3}$ & $00.001 \mathrm{mg} \mathrm{m}^{3}$ & Laser particle counter \\
\hline
\end{tabular}

Plant Pathology: The recently planted crops in farmlands within the study location were observed and some samples collected for laboratory analysis. Crop diseases were studied on all above-ground parts of crops in the farmlands within the vicinity of the study area. Crops in farmlands were visually observed for air pollutants symptoms and signs of the disease and where possible, on-the-spot identification of the causal pathogens of the disease was made based on characteristics and symptom types. Care was taken to differentiate between effects caused by air pollution and pathogens like fungi, virus and bacteria. However, Khan and Khan (2011) has associated various plant diseases to air pollution. They reported that air pollutants made crops vulnerable to attack by fungal, virus and bacteria. Besides causing direct damage, some air pollutants may also influence plant performance by influencing activities of microorganisms associated with the crops, especially pathogens as they draw nutrition from the host crops. In cases where field identification of air pollutantcausing agents could not be ascertained, diseased specimens were collected in polythene bags for laboratory investigation to establish the identity of the pollutant associated with the specific disease symptoms.

Table 4. National ambient air quality standards (USEPA, 2017)

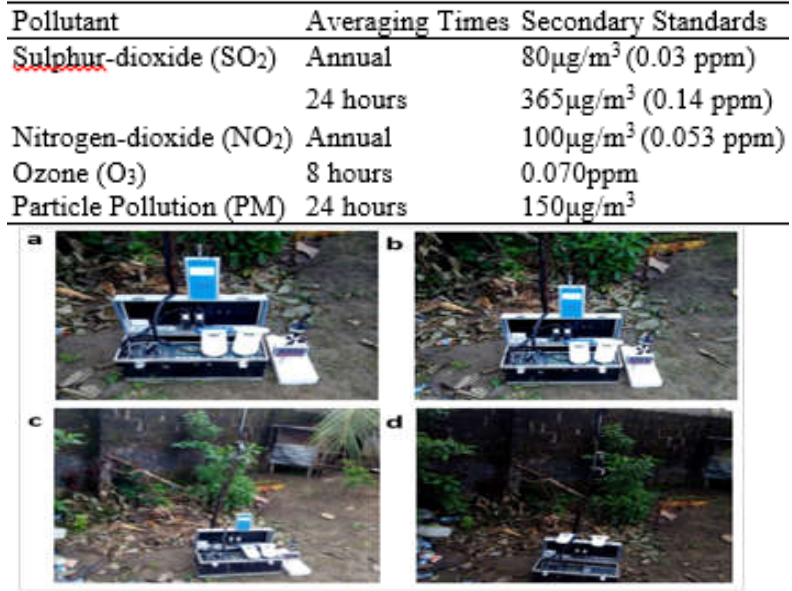

Fig 2. (a) and (b) Air quality monitoring instruments (c) and (d) Data capturing process

\section{RESULTS AND DISCUSSION}

Effects of air pollution on crop yield: The indicators of the effects of air pollution on crops captured at different locations in the study area are shown in Figure 3-8. Cucumber, cocoyam, yams, maize, okras, plantains, cassavas, pumpkins and pawpaw were some of the crops susceptible to air pollution damage in Eleme. Cocoyam, maize, okras and yams were the most sensitive crops followed by plantains. Cassavas, pumpkins and pawpaw were also affected as shown in figure 6. Crops reactions to air pollutants depend on the exposure characteristics such as exposure concentrations and duration, crop properties such as genetics, and external growth conditions such as the local weather conditions of the area (Brust, 2007; Bender and Weigel, 2003). 
Crops that are exposed to high concentrations of air pollutants are susceptible to infection by pathogens. Ozone, for instance, reduces the vitality of crops making them more susceptible to plant pathogens (USEPA, 2006; Fuhrer, 2009). The monthly results of air quality monitored at each selected location within area are presented in Figure $3-8$. The results show the mean and standard deviation for the months of dry season (December to February) and months of rainy season (July to September).

Sulphur Dioxide $\left(\mathrm{SO}_{2}\right): \mathrm{SO}_{2}$ mean values exceeded the USEPA standard for the protection of crops (see figure 4) at Aleto Eleme, Alesa Eleme and Agbonchia Eleme in the dry season; and exceeded at Aleto Eleme, Alode Eleme and Alesa Eleme in the rainy season. Short term exposure of crops to these levels of $\mathrm{SO}_{2}$ can cause sulphate to accumulate in crops vacuoles and reduce the rate of photosynthesis (Bender and Weigel, 2011). This can lead to the impairment of the metabolism processes in the crops resulting in cellular death according to Legge and Krupa (2002) as contained in Bender and Weigel (2011).

Nitrogen Oxides $\left(\mathrm{NO}_{\mathrm{X}}\right): \mathrm{NO}_{2}$ values exceeded the USEPA standard in Table 4 for the protection of crops for both dry and rainy seasons. Nitrogen oxides including $\mathrm{NO}_{2}$ contribute to the formation of ground level ozone, which has adverse damaging effects of plants. Continuous exposure of crops to the average concentrations of $\mathrm{NO}_{2}$ obtained at Aleto Eleme and Alesa Eleme in the rainy season may result in growth inhibition.
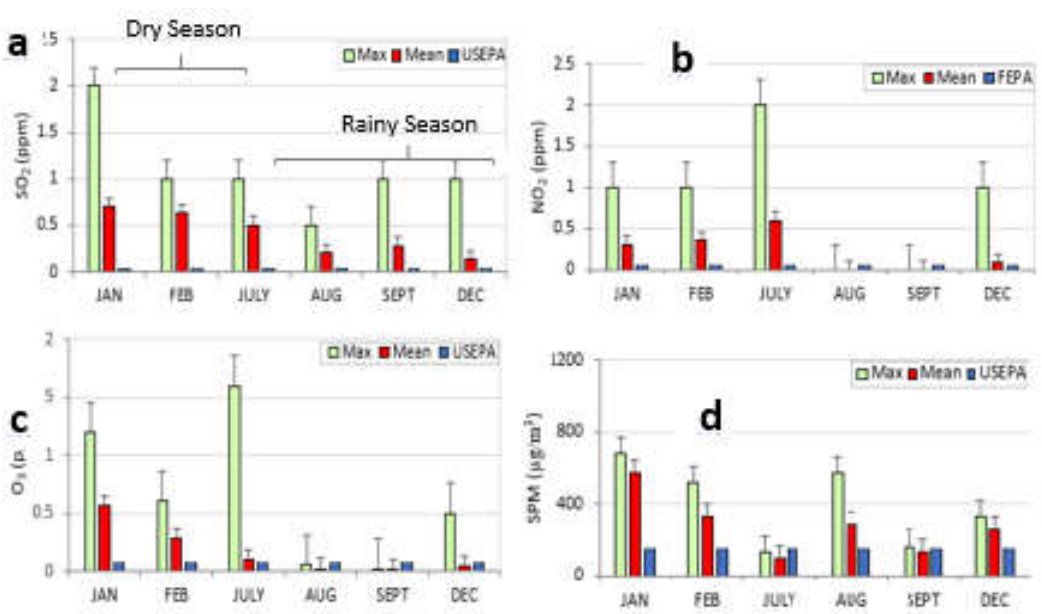

Fig 3. Variation in concentration of air quality parameters (a) - (d) Akpajo
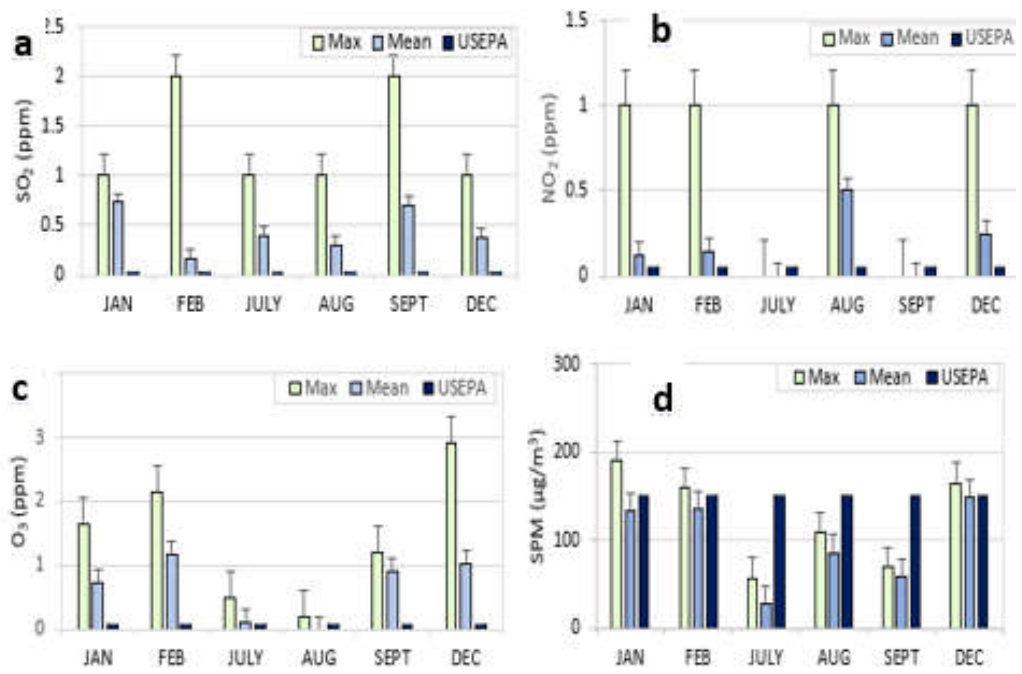

Fig 4. Variation in concentration of air quality parameters (a) - (d) Onne
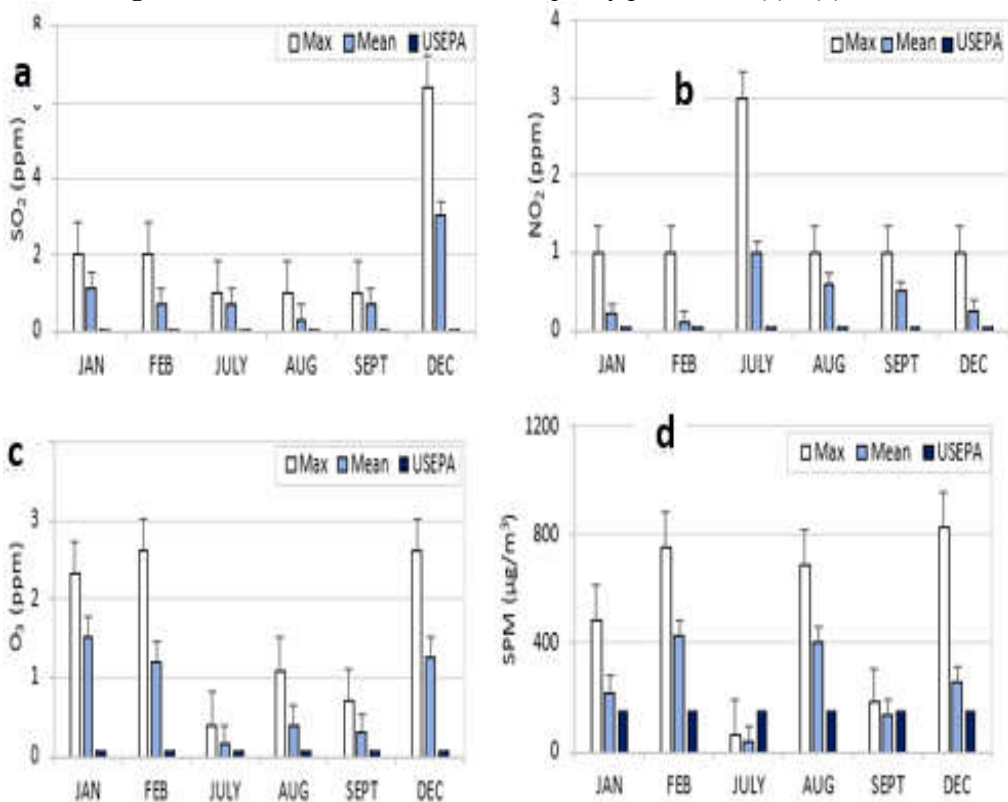

Fig 5. Variation in concentration of air quality parameters (a) - (d) Alesa 
Suspended Particulate Matter (SPM): Dry season average concentrations of SPM showed minimum value of $138.98 \mu \mathrm{g} / \mathrm{m}^{3}$ at Onne Eleme and maximum value of $386.38 \mu \mathrm{g} / \mathrm{m}^{3}$ at Akpajo (see figure 3), while the rainy season values showed minimum of $42.83 \mu \mathrm{g} / \mathrm{m}^{3}$ at Agbonchia Eleme and maximum of $190.17 \mu \mathrm{g} / \mathrm{m}^{3}$ at Alesa Eleme. Similarly, the average seasonal concentrations of particulate matter in the study area are presented in Figure 5. Concentrations of suspended particulate matter have greater impact within Akpajo Eleme in the dry season, followed by Aleto Eleme and Alesa Eleme. A reduction in the concentrations of SPM in the study area was observed in the rainy season (see figure 3-8). It shows slightly high impact in Alesa Eleme followed by Akpajo Eleme in the rainy season. Its concentrations were generally low in other locations within the study area. Although, SPM in the area was high averaged up to $386.38 \mu \mathrm{g} / \mathrm{m}^{3}$ in the dry season. Particulate particles in the form of black carbon (soot) were visibly seen deposited on some harvested yams in the area (see figure $6 \mathrm{j}$ ). This could be attributed to the prevalent of black carbon in the atmosphere of Rivers State. Particulate matter affects crops by coating and shading leaf surface and thereby causing decrease in the concentration of chlorophyll (Joshi and Swami, 2009; Seyyednejad, 2011). Particulate deposition on leaf interferes with gaseous exchange in crops by clogging the stomata causing increase in leaf temperature resulting in the retardation of the synthesis of chlorophyll (Seyyednejad, 2011).
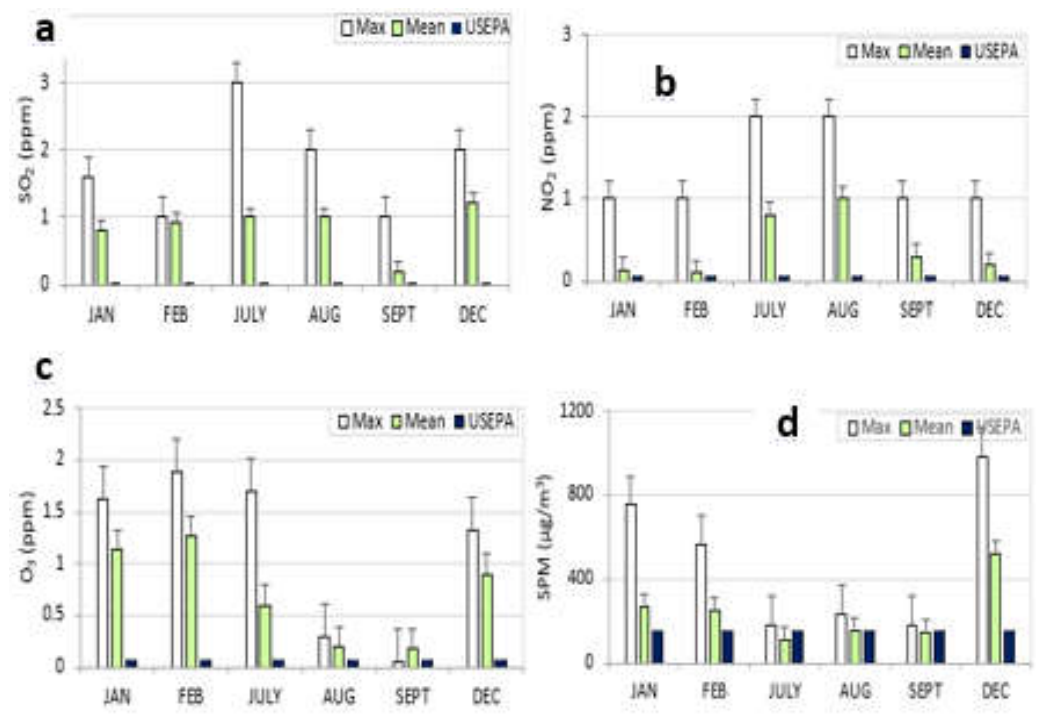

Fig 6. Variation in concentration of air quality parameters (a) - (d) Aleto
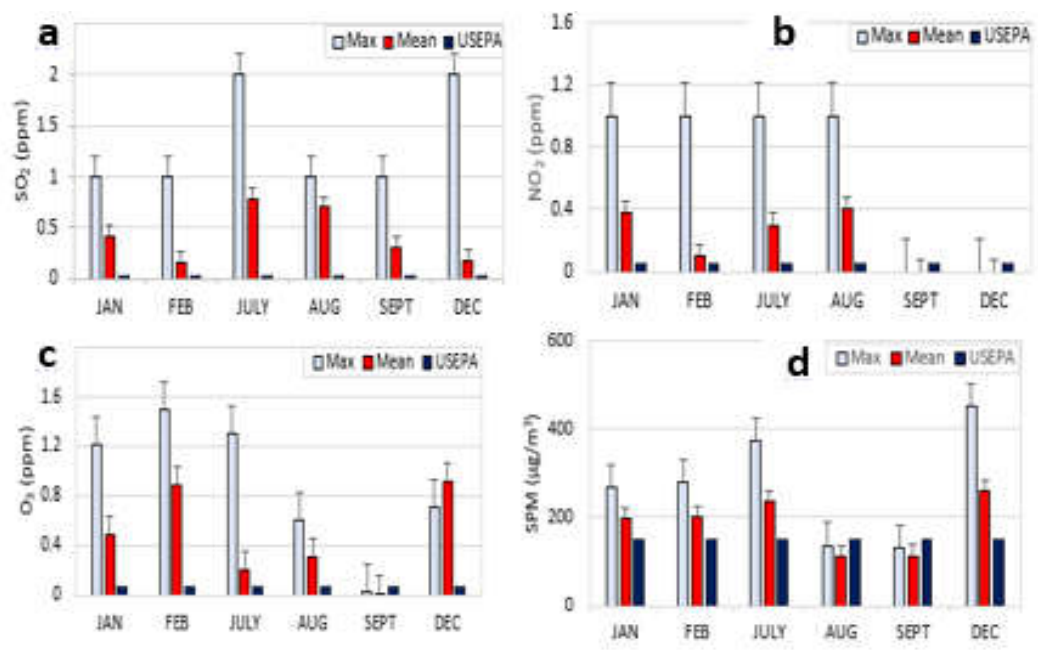

Fig 7. Variation in concentration of air quality parameters (a) - (d) Alode
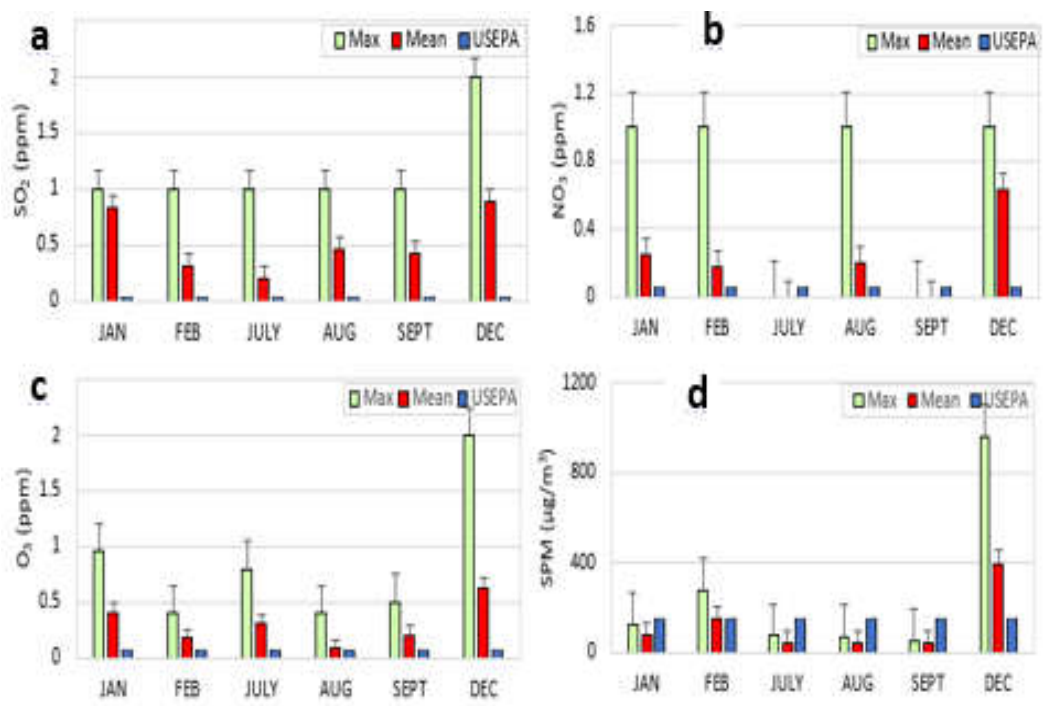

Fig 8. Variation in concentration of air quality parameters (a) - (d) Abonchia 
Photosynthesis activity is reduced in leaf surface coated with particulate matter causing a reduction in the total chlorophyll content. Particulate matter affects crops by coating and shading leaf surface and thereby causing decrease in the concentration of chlorophyll (Joshi and Swami, 2009; Seyyednejad, 2011). Particulate deposition on leaf interferes with gaseous exchange in crops by clogging the stomata causing increase in leaf temperature resulting in the retardation of the synthesis of chlorophyll (Seyyednejad, 2011). Photosynthesis activity is reduced in leaf surface coated with particulate matter causing a reduction in the total chlorophyll content. The crops in these areas may experience stunted growth due to longterm exposure to these levels of $\mathrm{NO}_{2} . \mathrm{NO}_{2}$ has highest impact within Agbonchia Eleme in the dry season followed by Akpajo Eleme as shown in figure $3-8$. However, it has least impact in Alode Eleme and Aleto Eleme. There is an increase in the concentrations of $\mathrm{NO}_{2}$ at Alesa Eleme and Aleto Eleme in the rainy season, which could be attributed to changes in wind pattern and the nearness of these two areas to facilities such as a refinery and petrochemical plants which serve as sources of air pollutants.

Ozone $\left(O_{3}\right)$ : Ozone showed average minimum concentration of $0.29 \mathrm{ppm}$ at Akpajo Eleme and average maximum concentration of $1.34 \mathrm{ppm}$ at Alesa Eleme in the dry season. Also, rainy season average values showed minimum of $0.04 \mathrm{ppm}$ at Akpajo Eleme and Maximum of $0.37 \mathrm{ppm}$ at Onne Eleme. Dry and rainy season average concentrations of ozone are presented in Figure 4. These values exceeded the USEPA standard for the protection of crops in both the dry and rainy seasons. Ozone shows a decrease in concentrations in the rainy season, (see figure 3). Onne Eleme shows highest concentrations in the rainy season followed by Aleto Eleme and Alesa Eleme. It is minimal within Agbonchia Eleme and Alode Eleme, and least within Akpajo Eleme in the rainy season (see figures $3-8$ ).

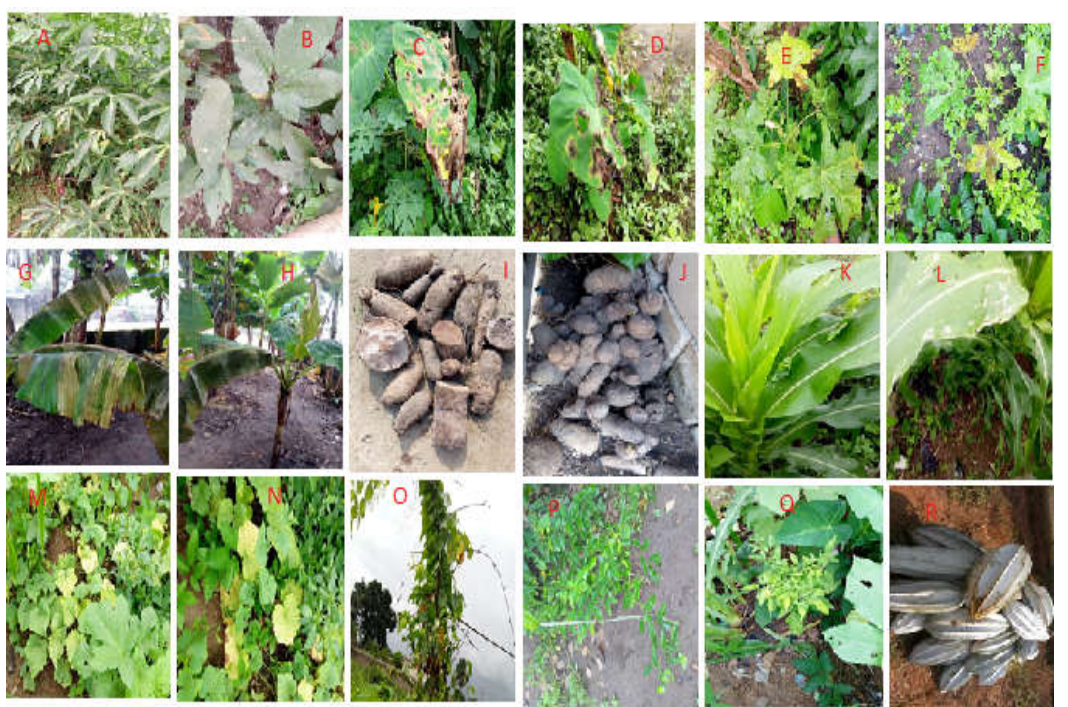

Fig 9. (a) $\mathrm{O}_{3}$ and $\mathrm{SO}_{2}$ effects on Cassava (b) Pumpkin (c) and (d) $\mathrm{O}_{3}$ damage to Cocoyam (e) and (f) effects of $\mathrm{O}_{3}$ and $\mathrm{SO}_{2}$ on Okra (g) $\mathrm{O}_{3}$ damage to Plantain and (h) Banana tree (i) and (j) Particulates deposit on harvested yams (k) and (l) $\mathrm{SO}_{2}$ damage to maize crop (m) and (n) $\mathrm{SO}_{2}$ damage to cucumber crop (o) and (p) air pollution effect on yam crop (q) $\mathrm{O}_{3}$ damage to pepper (r) effect on pumpkin.

Plant pathology: The plant pathology indicates the presence of chlorosis, membrane damage, metabolic inhibition and necrosis in cucumber, yam, cassava, okra and maize caused by $\mathrm{SO}_{2}$. Symptoms of $\mathrm{SO}_{2}$ damage observed in some crops in Eleme are dry whitish blotches, necrosis, and plasmolysis on leaves. This damaging effect was observed in cucumber, yam, okra, pumpkin, cassava and maize leaves as shown in Figure 6. It affects both the lower and upper surfaces of the leaves; however, the veins of the leaves remain green. Pumpkin, maize and okra were the most sensitive to $\mathrm{SO}_{2}$ damage (see Figure 6). The University of Illinois (2002), Department of Crop Sciences reported that short-term exposure (4-24 hours) of crops to $\mathrm{SO}_{2}$ concentration levels of $0.25-0.5 \mathrm{ppm}$ results in acute injury. Okra, cucumber and maize are the crops most sensitive to $\mathrm{SO}_{2}$ exposure, while pumpkin crop has the ability to resist $\mathrm{SO}_{2}$ effect. $\mathrm{SO}_{2}$ effects on the crops were more pronounced in the rainy season when there was high sunshine and relative humidity. The pathology revealed the presence of brownish-black spot on the leaves of the crops caused by $\mathrm{NO}_{2}$. This results in leave bleaching and stunted growth (Rao and Rao, 2005) causing reduction in crops yield according to Lal (2016). Again, it was observed that ozone causes pre-mature yellowing and falling of leaves in plantain, maize and cassava. It is the main cause of leaf dis-coloration and curling of sepals of some crops in Eleme. This phytotoxic air pollutant affects most crops in Eleme. Symptoms of ozone exposure found in crops in were flecks on upper leave surface, stunted growth, reddening and bronzing. These are the observed mild effects of ozone on crops in the area. Severe ozone effects are collapse of leaves/tissues, necrosis and chlorosis were found in cocoyam, okra and plantain (figure 9d, $\mathrm{e}, \mathrm{f}$ and $\mathrm{g})$. 
The effect ozone on crop leaves and tissue makes the crops easily attacked by Alternaria $s p$ pathogens resulting in leaf blight (Brust, 2007). The concentration levels of $\mathrm{O}_{3}$ obtained in the dry and rainy seasons pose chronic effects to farmland crops in Eleme. High concentrations of $\mathrm{O}_{3}$ of this sort have been found to decrease the yields in wheat, soybean and rice (Marshall et al., 2005). Fuhrer (2003) ascribed the reduction in crops yields decrease in photosynthetic rate, accelerated ageing and changes in carbon distribution caused by long-term exposure to ozone.

Estimation of crop loss: It was difficult to estimate agricultural yield losses caused by air pollution in the

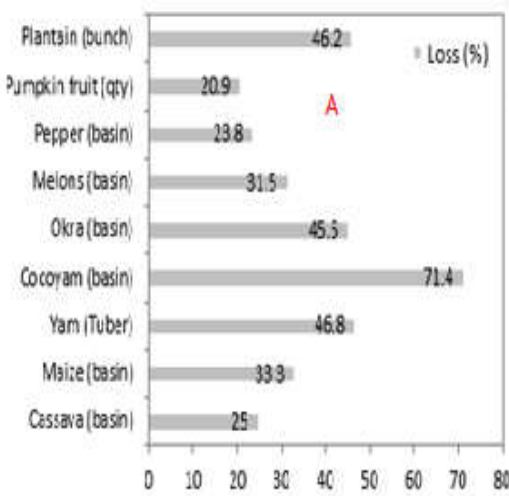

area. This is due to the subsistence type of farming practiced by the farmers, absence of appropriate storage system and lack of information on the actual annual farm products. However, in order to get an estimate of the yield losses, the local farmers were verbally interviewed on their experiences during harvest, their homes were also visited and their harvested farm products in stores were assessed. The harvested farm products in local barns or stored in one way or the other were counted and approximated. The estimated losses are based on farm produce harvested between the 2016/2017 farming season and 2017/2018 farming season from an average of 0.05 hectares of farmland (see figure 10a and $b$ ).

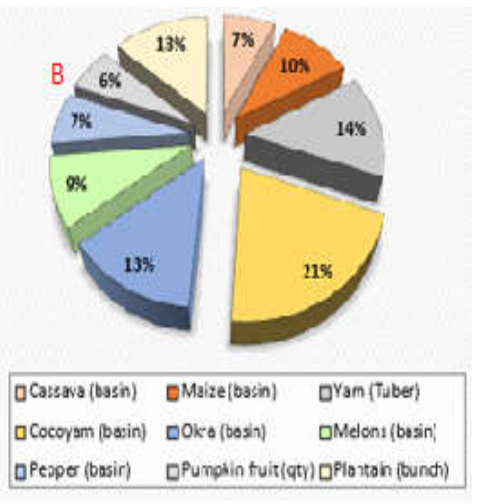

Fig 10. (a) Percentage estimated yield losses in crops due to air pollution (b) losses in total number of crops analyzed.

Statistical evaluation: Analysis of variance (ANOVA) was applied using Excel 2019, to determine the variation in agricultural yield due to air pollution within the study area. The analysis was carried out at $95 \%$ confidence level. See summary of ANOVA in table 5.

Table 5. ANOVA of crop yield due to air pollution

\begin{tabular}{lllllll}
\multicolumn{7}{c}{ Table 5. AN } \\
\hline Source of Variation & SS & df & MS & F & P-value & F crit \\
\hline Between Groups & 45361.11 & 8 & 5670.139 & 20.26256 & $6.88 \mathrm{E}-05$ & 3.229583 \\
Within Groups & 2518.5 & 9 & 279.8333 & & & \\
Total & 47879.61 & 17 & & & & \\
\hline
\end{tabular}

The result shows that cocoyam is the most sensitive to air pollution with the greatest losses of $71.4 \%$ (see figure $10 \mathrm{a}, \mathrm{b}$ ). This is followed by yam, plantain and okra with crop yields losses of $46.8 \%, 46.2 \%$ and $45.5 \%$ respectively. Maize and melons were moderately affected with yields losses of $33.3 \%$ and $31.5 \%$ respectively. Similarly, cassava, pepper and pumpkin were the least affected crops with yields losses of $25.0 \%, 23.8 \%$ and $20.9 \%$ respectively as shown in figure $10 \mathrm{a}$. Thus, on the whole, air pollution is estimated to cause agricultural crop losses averaging approximately $38.3 \%$ per year (annually). Statistical analysis of variance (ANOVA) shows that there is a significant decrease in crop yields in the 2017/2018 harvest season compared to the 2016/2017 harvest season $(\mathrm{F}=20.3 ; \mathrm{p}<0.05 ; 95 \% \mathrm{Cl}$. $)($ table 5$)$. Ukegbu and Okeke (1987) reported that crop yield losses ranging from $10 \%$ to $100 \%$ in Izombe Ohaji/Egbema/Oguta Local Government area of Imo state due to air pollution was caused by gas flaring. Also, Chikaire and Godson-ibeji (2016) showed that crop growth and crop yield are negatively affected by air pollution in Nigeria due to gas flaring. Again, Olisemauche and Avwerosuoghene (2015) reported that air pollution caused by gas flaring has adverse effects on plantains resulting in little and tiny bunches.

Conclusion: Subsistence agriculture which revolves around the production of food crops is the most common farming system practiced. Also, field monitoring and data analysis indicate that concentration of $\mathrm{SO}_{2}, \mathrm{NO}_{2}, \mathrm{O}_{3}$, and particulates exceeded the USEPA standards for the protection of crops. However, ozone, nitrogen oxides and sulphur 
dioxide at high level adversely affected the crops in Eleme. While suspended particulate matter (SPM) was slightly high when compared with standard but lower than other parameters. Although, cucumber, cocoyam, yams, maize, okras, plantains, cassavas, pumpkins and pawpaw were some of the crops susceptible to air pollution damage. The study shows that air pollution causes approximately $38.3 \%$ crop losses annually. Hence, the level of air pollution significantly affects agriculture within the study location.

Acknowledgements: Authors are grateful to IBIBATH Multi Services, Port Harcourt, Nigeria for their support.

\section{REFERENCES}

Adams, RM; Ledeboer, MV; McCarlb, BA (1984). The Economic Effects of Air Pollution on Agriculture: An Interpretive Review of the Literature. Special Report 702, Agricultural Experiment Station Oregon State Kniversity, Corvallis.

Bender, J; Weigel, HJ (2003). Ozone stress impacts on plant life, in: Ambasht R.S., Ambasht N.K. (Eds.), Modern Trends in Applied Terrestrial Ecology, Kluwer Academic/Plenum Publishers, New York, pp. 165-182.

Bender, J; Weigel, HJ (2011). Changes in atmospheric chemistry and crop health: A review. Agronomy for Sustainable Development, Springer Verlag/EDP Sciences/INRA, 2011, 31 (1), 81-89.

Brust, GE (2007). Air Pollution Effects on Vegetables. IPM Vegetable Specialist.

Chikaire, JU; Godson-ibeji, CC (2016). Consequences of Environmental Pollution on Agricultural Productivity in Developing Countries: A Case of Nigeria. Inter. J. Agric. Food Res. 5 3, 1-12.

Fuhrer, J (2009). Ozone risk for crops and pastures in present and future climates, Naturwissenschaften 96, 173-194.

Fuhrer, J; Booker, F (2003). Ecological issues related to ozone: agricultural issues. Environment International. $29,141-154$.

Hindawi, I (1970). Air Pollution Injury to Plants, U.S. department of Health, Education and welfare, National Air pollution Control Administration Publication No. Aap-71, Washington DC, p 13.

Joshi, PC; Swami, A (2009). Air Pollution Induced Changes in the photosynthetic Pigment of selected plant species. J. Environ., Boil. 30:295-298.

Khan, MR; Khan, MM (2011). Plants Response to Diseases in Sulphur Dioxide Stressed Environment. Plant Path.. 10: 1-12.
Lal, N (2016). Effects of Acid Rain on Plant Growth and Development. e-J. Sci. Technol. (e-JST)

Legge, AH; Krupa, SV (2002). Effects of sulphur dioxide, in: Bell J.N.B., Treshow M. (Eds.), Air pollution and plant life, John Wiley \& Sons, Chichester, pp. 135-162.

Marshall, F; Ashmore, M; Hinchcliffe, FA (2005). Hidden threat to food production: Air pollution and agriculture in the developing world. International Institute for Environment and Development, Gatekeeper Series. no. 73.

Olisemauche, OO; Avwerosuoghene, OP (2015). The effect of gas flaring on Agricultural production of Okpai, Ndukwa East Local Government Area, Delta State, Nigeria.

Rao, MN; Rao, HVN (2005). Air Pollution, Tata Mc-Graw Hill Publishing Company Limited, New Delhi, India, ISBN 9780074518717. International Edition, 22 ${ }^{\text {nd }}$ reprint.

Rupakheti, M (2015). Air pollution impacts on Agriculture. Institute for Advanced Sustainability Studies (IASS), Potsdam, Germany. Media regional Training, ICIMOD, Kathmandu.

Seyyednejad, SM; Niknejad, M; koochak, H (2011). A Review of Some Different Effects of Air Pollution on Plants. Res. J. Environ. Sci. 5 (4): 302-309.

Ukegbu, D; Okeke, AO (1987). Flaring of Associated Gas Oil and Gas Industry: Impact on Growth, Productivity and yield of selected farm crops in Petroleum Industry and the Nigeria Environment, Proceedings of 1987 Seminar, NNPC Lagos.

UNEP (2011). Environmental Assessment of Ogoniland. United Nations Environment Programme. Web: http://www.unep.org

University of Illinois (2002). Plant Damage from Air Pollution. Report on Plant Disease. Department of Crop Sciences.

USEPA (US Environmental Protection Agency) (2006) Air Quality Criteria for Ozone and Related Photochemical Oxidants, Report no. EPA/600/R-05/004aF-cF, US Environmental Protection Agency, Washington, DC.

USEPA, (2017). NAAQS Table | Criteria Air Pollutants | US EPA https://www.epa.gov/criteria-air-pollutants/naaqstable. Accessed 23 April 2019.

Yorkor, B; Leton, TG; Ugbebor, JN (2017). The Role of Meteorology for Seasonal Variation in Air Pollution Level in Eleme, Rivers State, Nigeria. J .Sci. Res. Reports. 17(3): 1-17. 